\title{
Desacralizing Secularism
}

\section{S. Parvez Manzoor}

No Muslim endeavor to face the intellectual challenge of the western tradition can afford to ignore the critical discourse of postmodernism or fail to recognize the Nietzschean claim about truth's complicity with power. Secularism as truth, as doctrine, therefore, cannot be separated from the theory and practice of secular power. As the praxis of statecraft, secularism claims universal sovereignty, and as the theoria of history, it subordinates all religious and moral claims to its own version of the truth. The secularist enterprise, furthermore, has been immensely successful in transforming the historical order of our times. But as such, it is a subject proper to the discipline of (political) history and merits the Muslim scholar's fullest attention there.

Secularism as a doctrine, as an -ism, on the other hand, falls squarely within the province of philosophy and the history of ideas. In order to apprehend the secularist gospel and its discontents, one needs to contemplate, as it were, the ideational visage of secularism. It is this aspect of secularism - the mask of truth worn by the secularist will-to-power-that the present article intends to uncover. Thus, the secularism that is examined here is not a sociological theory but rather a philosophical paradigm, not an empirical fact but rather an ideological axiom. This survey is divided further into two parts: secularizing theories in sociology and politics from the focus of the present essay. Secularism in philosophy, theology, and science will be treated in the second installment.

\section{Secularism or Sacralization?}

Secularism, like any darling child, has many names. In contemporary literature it is presented (either humbly) as a rejection of ecclesiastical authority, a model for pluralism, a theory of society, a doctrine of governance or (augustly) as a philosophy of history, a creed of atheism, an epistemology of humanism, or (even more grandiosely) as a metaphysics of immanentism that corresponds to the ultimate scheme of things. Within the academic discourse, it is also customary to accord it an almost Socratic definition and to distinguish its various manifestations as a process of history (secularization), a state of mind and culture (secularity), and a theory of truth (secularism). (One may note the close

S. Parvez Manzoor is an associate of and advisor to the International Institute of Islamic Thought, Herndon, Virginia. 
affinity of these terms with modernity, modernization, and modernism!) Needless to say, not everyone championing its cause ascribes to all these claims, nor is every expression of the secularist, this-worldly, conscience, and piety antithetical or inimical to Islam.

The first point to note is that western attempts to define secularism and its derivatives are not value-neutral and testify to the existence of the intense polemical climate within which these concepts are evoked. For instance Harvey Cox, a modern Christian apologist of secularity, asserts that "secularization is the liberation of man from religious and metaphysical tutelage, the turning of his attention away from other worlds and towards this one." Previously, however the Christian church was not as enthusiastic and regarded it as a punitive ideology, for secularization at that time simply denoted a judicial measure of confiscating ecclesiastical property for "worldly" use by individuals or the state.' It is only recently that Christian thinkers have started to modify their position on secularization. Dietrich Bonhoffer, for example, protested the antithesis of ecclesiasaeculum, which is axiomatic to modern individuals, and argued that secularization "represents a realization of crucial motifs of Christianity itself." Hence, Bonhoffer pleaded further, the term was meaningless and should be abandoned. $^{2}$

The whole problem of Christian complicity with the modern has been the subject of an exhaustive and incisive debate and need not detain us here. ${ }^{3}$ Suffice it to say that sociologists, for whom the term "secularization" refers to an "empirically available process of great importance in modern western history," find no reason either to abandon the term or to agree with Bonhoffer. ${ }^{4}$ On the contrary, they insist that secularization, as a fait social, can be defined positively as "the process by which sectors of society and culture are removed from the domination of religious institutions and symbols." The typical manifestation of secularization, then, would be the separation of church and state, the expropriation of church lands, the emancipation of education from ecclesiastical authority, and other similar elements. Thus, for all its discomforts to the church, secularization continues to be the cardinal doctrine of sociology.

Belatedly, however, some sociologists have come to the realization that, scientifically speaking, secularization is an inadequate category of societal analysis. According to David Martin, for instance, far from providing an objective description of modern society with scientific validity, the term "secularization" acts mainly as "a tool of counterreligious ideologies." (We need, however, to question the common assertion that fundamentalism is a revolt against modernity and secularism. Inasmuch as its metaphysical orientations are toward immanentism, it may be regarded as a variant of modernistic secularism. Hence, it is not merely accidental that there is so little love between traditionalists and fundamentalists!) Other moderate critics of secularization theory, who would not dismiss it entirely, have also begun questioning its intellectual under- 
pinnings. They readily concede today that "secularization, as the integrative idea of social change in the modern world, is seriously flawed."

A recent critique further reveals that the theory is basically "a hodgepodge of loosely employed ideas rather than a theory," and that "existing data simply do not support the theory." Similarly, the persistence of religion in the heart of secularized societies, which suggests that "religion is perhaps truly ubiquitous in human cultures," and the fact that religion has reemerged as a significant factor in the articulation of sociopolitical reality in more countries than ever before, challenge the assumptions of the secularization thesis. Even more embarrassing for its supporters is the disclosure that secularization theory is one "scientific" theory that traditionally has not turned to empirical facts for its authentication. Indeed, a recent study exclaims: "Before the mid-twentieth century essentially no empirical research and, hence, no foundation for challenging secularization theory existed."

The most cogent refutation of the secularization thesis, few would disagree today, has come from the recalcitrant forces of history. It is history rather than theory that has refused to redeem secularism's claim about the disappearance of religion in the age of science and enlightenment. The death of the sacred remains more of a vain secular hope than a probable historical scenario. And yet despite its spectacular failure, sacralization theory has not been totally abandoned, not least because it serves a useful purpose in modernity's ideological polemics against its detractors within the West or against other cultures from without. Needless to say, this ideological commitment is also at work behind recent efforts directed toward the restitution and revision of this theory. The persistence of religion in the midst of secular modernity, some secularist theorists point out today, is due to its privatization, for secularization implies not the extinction but rather the privatization of religion. However, according to another revisionist,

the assignment of religion to the private spheres is like having one's cake and eating it too. One can hold steadfastly to the Enlightenment image of the demise of religion and still account for its embarrassing persistence. It is not necessary to establish a timetable for the disappearance of religion. ${ }^{10}$

Clearly, the modern advocacy of the secularization thesis stems from an ideological commitment rather than from any fidelity to the scientific method. Even the sociologist has to concede that secularization is more than a sociostructural process, for it affects the heart and soul of a society's symbolic and cultural world. It manifests itself in "the decline of religious contents in the arts, in philosophy, in literature and, most important of all, in the rise of science as an autonomous, thoroughly secular perspective on the world." The secularization of societal institutions, then, leads to the secularization of consciousness and bestows upon the modern individual his/her peculiarly antireligious prejudices and passions. 
Today, the term does not merely describe what happens in history but expresses a value, perhaps the most sacrosanct value of our age. Secularization represents more than a Promethean bid for the banishment of God from the governance of human polis. The idea of secularization itself has become sacralized and secularism as doctrine has now replaced secularization as process. It has turned itself into a faith: a faith in humanity and a faith in progress, both a secularized faith and a faith in secularization. ${ }^{12}$

\section{The Crisis of Authority}

Whatever the cogency and validity of the secularist argument, it is contingent upon a conception and understanding of "religion" that is idiosyncratically western. The modern definition of religion as "the exclusive zone of human reality for the experience of the "holy" "bears the distinctive insignia of the secular individual and applies only to his/her world. The intellectual cosmos and life-world of the premodern person of faith is a unity: it knows of no religious and nonreligious dominions. No faith regards itself as anything but a total system of morality and knowledge that can cope with any human situation in terms of meaningful answers. None is willing to disenfranchise itself to the extent of positing that there could be spheres of human experience outside its arbitration. ${ }^{13}$ For the devotee, there is no optional metaphysics of belief, only the integrative life-world of faith. ${ }^{14}$ Indeed, even anthropologists argue that there can be no generic definition of "religion," a universal genus of which all particular religious traditions are mere historical variations, "not only because its constituent elements and relationships are historically specific, but because that definition is itself the historical product of discursive forces."1s

Paradoxically, if the peculiarly modern notion of "religion" is the creation of the secular individual, it was the sacred that gave birth to the secular in the first place and legitimated it as an autonomous domain of human reality! (The "sacred" and the "secular" here refer to institutional divisions within the western society and do not allude to any putative schism within the human soul.) This fateful dichotomy, upon which most of modernity's self-authentication hinges, owes its genesis to one of the bittersweet ironies of history. Its roots lie in the sacred nature of Roman politics, where religious and political activity could be considered as almost identical. It is within that context that the concept of authority (auctoritas) originally appeared and came to be distinguished from power (potestas). The most conspicuous characteristic of those in authority, notes Hannah Arendt in a particularly suggestive and seminal study, is "that they do not have power. Cum potestas in populo auctoritas in senatu sit, "while power resides in the people, authority rests with the Senate.'

For Romans, the binding force of this authority, "more than advice and less than command," is connected closely with the religious force of auspices. Further, this conception of authority is similar to that of the 
Sunnah in the Islamic tradition: precedents, deeds of the ancestors, and customs that grew out of them are deemed paradigmatic and binding. Indeed the expression auctoritas maiorum, which may be translated uninhibitedly as sunnat al awwalin, became identical for the Romans with normative models for actual behavior-with tradition. However, when the church succeeded in overcoming "the anti-political and anti-institutional tendencies of the Christian faith" and embarked upon her political career in the fifth century (after Constantine the Great), she adopted the Roman distinction between authority and power. But most significantly, she claimed for herself the old authority of the Senate and left the power of the state to the princes of the world. Thus were sown the seeds of strife between regnun and sacerdotium and also of the "sovereignty" of the state within its own secular realm!

According to Arendt, this continuity of the Roman tradition had two consequences for the history of the West: one, the permanence of the clerical institutions, the other, the degradation of the political ones: "On one hand, the miracle of permanence repeated itself once more; for within the framework of our history the durability and continuity of the church as a public institution can be compared only with the thousand years of Roman history in antiquity. The separation of church and state, on the other hand, far from signifying unequivocally a secularization of the political realm and, hence, its rise to the dignity of the classical period, actually implied that the political had now, for the first time since the Romans, lost its authority and with it that element which, at least in Western history, had endowed political structures with durability, continuity, and permanence." 17

The Christian identification with auctoritas, which insinuated that the church represented a truth higher than the mundane concerns of earthly empires, had the unintended consequence of removing God from the realm of the political-indeed of dispensing with God as the organizing principle of western civilization altogether. It also meant that the Roman unity of religion, authority, and tradition that had conferred upon the political realm its foundational pathos and its imperial grandeur was ruptured. Hence, having acquired this insight, Arendt can claim justly that

whenever one of the elements of the Roman trinity, religion or authority or tradition, was doubted or eliminated, the remaining two were no longer secure. Thus, it was Luther's error to think that his challenge of the temporal authority of the church and his appeal to unguided individual judgement would leave tradition and religion intact. So it was the error of Hobbes and the political theorists of the seventeenth century to hope that authority and religion could be saved without tradition. So, too, was it finally the error of the humanists to think that it would be possible to remain within an unbroken tradition of Western civilization without religion and without authority. ${ }^{18}$ 
In fact, for Arendt, "the decline of the West" consists primarily of "the decline of the Roman trinity of religion, tradition and authority."

Similar concerns have been expressed by Michael Harrington, who in a recent work mourned the death of the "political God of the West" with great eloquence, anguish, and sorrow. ${ }^{20}$ For him, the eclipse of religion entails preeminently a crisis of political theory and a loss of authority. The fact that the West, for the past two centuries at least, has been a civilization without an avowed faith is therefore, for him, a cause of acute metaphysical pathos and spiritual disquietude. Prior to His "demise," notes Harrington, the societal God of Judaeo-Christianity possessed certain political attributes that included:

1. The legitimization of established power and sometimes a revolt against it;

2. The transcendent symbol of common consciousness of an existing community;

3. The foundation of all other values;

4. The organizing principle of a system of the authoritative allocation of social rules (God of feudalism) or the motivating and ethical principle of individual mobility (God of capitalism);

5. The guarantor of personal, ethnic, and national identity; and

6. A philosopher for the non-philosophers, including the illiterate. $^{21}$

God, claims Harrington, was "the most important political figure in the West" and, hence, His banishment from public consciousness has had calamitous social and political consequences for the western body politic. Some of the most noticeable among them are:

1. A crisis of legitimacy in the late capitalist society as one of the prime motives for non-coerced obedience and acquiescence in the social order begins to disappear;

2. The shift from the "Protestant ethic" to the compulsory hedonism of unplanned and irresponsible growth;

3. The appeal of totalitarian movements as substitutes for religious solidarity;

4. The loss of a philosophic "commonsense" basis of responsibility before the law;

5. The dangers of .... a purely technological and instrumental attitude towards nature;

6. the decline in the sense of duty toward unborn generations; 
7. the loss of one of the most important constituent elements in both group and personal identity;

8. the relativisation of all values and a resultant crisis of individual conscience;

9. the weakness of the "superego," and the cult of the self; and

10. the thinness and superficiality of the substitutes of religion by sex and drugs and so forth. ${ }^{22}$

Harrington's search for legitimacy within modern sociopolitical structures also entails the coming together of the people of "authentic humanism" and "religious faith" in the West, because capitalism, the chief source of mindless de facto atheism, is the enemy of both of them. Against the tyranny of the thoughtless, normless, selfish, hedonistic individualism that is the gift of capitalism, so to speak, he hopes that there could emerge a consensus based not on the affirmation of the same conception of the world, humanity, and knowledge but on a common will to action. Further, even if Harrington imagines it as arising in the West, this consensus has to be universal.

No one need deny the moral urgency and persuasive force of Harrington's sentiments, yet the tyranny is that his "social democratic" vision cannot free itself from the compulsion to compromise. At the end of his superbly conducted tour of the western intellectual landscape, his gaze refocuses itself on the familiar mileposts of his own ideological pastures. Like a mole, Harrington would have us burrow our way through the mountain of spiritual crisis in a spirit of political compromise. Little wonder that the rocky impediments of unbelief allow him only the comforts of a mole's tunnel vision. He lacks the power of faith that moves mountains. The grand coalition of "atheistic humanism" and "religious faith," which is offered as a path to planetary conscience, is a half-measure begotten of half-truths and is unlikely to end the apartheid of "faith" and "reason" that is the legacy of the West and its civilization to our age.

Despite Harrington's justified strictures, however, modern thought neither denies the "political necessity of religion" nor dismisses the indispensability of "civil theology" for political order. Nor, in fact, is there any real dispute about the need for "transcendentals." Rather, the principal cause of the legitimacy crisis is the realization that the basic religious tradition of the West, as a religious tradition, can no longer provide the core values of western society. A revival of Judaeo-Christianity, a return to the theocratic past, is, in other words, both impossible and undesirable. The roots of the present political crisis are cognitive, epistemological, and metaphysical, and no "pragmatic" acceptance of the Christian solution could appease the secularist conscience. That which does not remove the seeds of cognitive doubt is unworthy of the secularist's voluntary societal assent. 
In any genuine dialogue with the atheistic humanist, then, the Muslim would be justified in insisting a) that the western experience of the "death of God" is quite provincial and parochial and b) that religiously and politically it does not represent humanity's ultimate longing for a vacuous emancipation and enlightenment-both the malaise and the remedy are appropriate only for the western patient. It would be equally appropriate to point out that the western individual's loss of faith represents the logical fulfillment of the "secularistic" dogmas of the western creed. One could also take comfort that Islam, as a civilization, has never renounced God. In fact, dismissing all the oracles of doom would not be an unreasonable Muslim reaction, nor would be the search for epistemologically and experientially cogent Islamic answers.

As an individual of faith, however, the Muslim should tell the secularist that humanism, whether Christian or atheistic, Marxist or liberal, cannot end the present crisis of values, for as long as the individual regards himself/herself as the locus of his/her values and concerns, he/she is unable to judge his/her own conduct. Only by defining himself/herself from an external point of reference can an individual hope to acquire the trappings of a cognitive and moral arbitration. The religious individual has always measured the cardinal point of his/her personality and civilization against God - the external (transcendent) source of all values. Before the Muslim can make common cause with the atheistic humanist, he/she has a right to ask whom the latter accepts as referee.

What is true of Harrington is true of the secular individual in general. The latter's epistemology of questions, loss of meaning, indeed the uncertainty of being is the natural cry of the self-reproaching and tormented soul, known in the parlance of the Qur'an as al nafs al lawwämah. By renouncing God, the secular individual has been rendered impotent in the face of the problems of knowledge and power. It has always been common knowledge that theology and political philosophy are indispensable to each other. The modern debate over the legitimation of knowledge also shows that even epistemology without theology is not a viable option, for with the "death of God" comes not only the darkness of the human soul but also the blankness of the human mind. Without a transcendent referent there can be no science of morals, but only the cognitive uncertainty of relativism. Without a beyond there is no categorical imperative, but only the whim of subjectivity.

\section{The Clerical Paradox}

Secularization, as we have seen, is more than a process in the mind, a loss of religious belief, and an acceptance of the scientific view of the world. It is an institutional arrangement, a structural differentiation, and an ideational division of labor whereby the sacred is separated from the realm of power, from the secular. It is the sacred that gives birth to the secular by hiding, as it were, behind a veil. Where the sacred is not self-conscious or 
narcissistic enough to conceal itself in a sanctuary or to confine it within an inviolate haven, the secular also remains unnoticeable. Such was the case in traditional Islamic societies, where the sacred had no special retreats and the secular had no boundless freedom outside them. With Christianity and Buddhism, however, it is a different matter. The church or Sangha (the Buddhist monastic orders) represents an institution specifically concerned with "religion" in counterposition with all other institutions of society. The confinement of religious activities and symbols to one institutional sphere ipso facto defines the rest of the society as "profane" and thus outside the jurisdiction of the sacred. It is this arrangement that transforms the world outside into the saeculum, the profane domain with which the sacred had neither any concern nor quarrel. The logical development of this, notes a modern scholar, may be seen in the Lutheran doctrine of two kingdoms, "in which the autonomy of the secular world is actually given a theological legitimation." ${ }^{, 23}$ Secularity, it would appear, is from the very start a Christian ambition and a Protestant necessity!

Muslim societies, as claimed in indigenous and foreign lore, did not have any sacerdotal institutions or churches and hence were spared the sacred-secular dichotomy of the West. Whatever the validity of this thesis, early Islam did witness some attempts to establish a theocracy and, in the event of its failure, to create a surrogate imämah that was more like a papacy than a political government. Nonetheless in practice, not even Shi'ism, which championed the cause of an infallible imämah, severed completely its bonds with history, for it remained loyal to the common Islamic ideal of the unity of the religious and the political. Like Sunnism, it simply responded to the challenges of history and to the perennial state-religion tension found in Muslim societies with the intellectual and moral resources of a single unified vision.

Notwithstanding the received wisdom, Muslim civilization is heir to a peculiar set of tensions that have been as detrimental to its body politic as the most nefarious conflict between the church and the state in the West. Although the Muslim state, as an institution, was all-pervasive and never had to contend with a challenge of the nonexistent church, in terms of ideology it was a different matter altogether: The state, despite its absolute power, never succeeded in establishing its autonomy and legitimacy and thus remained merely the coercive forearm of a political society that could have no pretense to any redemptive functions. The body politic of Islam (the Muslim ummah) expressed its ultimate aspirations through the sacred law, whose legitimate guardians were the ulama and not the sultan. In other words, civil society was sovereign over the state, and the ruler did not represent the body politic but merely embodied his personal rule or misrule. Or, seen differently, the state as the locus and seat of sovereignty did not exist.

Despite the absence of the church and of the concomitant church-state rivalry, Islamic civilization generated its own sources of tension between the sacred and the secular. It was forced to choose, as it were, between two 
contending texts: that of the sacral kingship of the khalifah and that of the clerical authority of the ulama. What triumphed in Muslim history can only be characterized as a duality: the state as the body (phenoumenon) of Islam and the law as its spirit (noumen). The state shared power with no rival association but was not the ultimate focus of Muslim loyalty; the ulama possessed no institution of their own but acted as the expounders of Islamic dogma! Institutional power without a legitimating text and textual authority without any institutional power: a this-worldly state in the service of the other-worldly norm! Indeed, the mutual dependency of the one upon the other has produced a highly immanentist reading of the supremely transcendental text of the revelation. In the discourse of the jurists, raison d'islam has become indistinguishable from raison d'état!

The triumph of secularism, or the encroachment upon the Muslim order by western powers, has disturbed seriously the traditional equilibrium between state and clergy. The modern state, which had become too secular and had emancipated itself from the ulama's influence, is under siege today. The clergy not only is very much a part of contemporary Shi'ism, especially in Iran, but is gaining strength in other parts of the Muslim world as well. Today, it aspires to assuming special sacerdotal functions within Muslim societies and has even adopted the nontraditional term of "clergy" with alacrity. Contrary to populist rhetoric, it appears that the secularization of Muslim societies is in full swing. In fact, according to a modern observer, the most powerful factor against the realization of the professed and sought-after unity of the sacred and the secular in Islam is the emergence of the clergy in recent times. ${ }^{24}$

Institutionally and sociologically, then, the clergy is by default the progenitor of secularism. Little wonder that the secularist ideal expresses itself in terms of a revolt, institutional as well as intellectual, against clerical hegemony. Thus the secularist passion for purging western societies of all vestiges of ecclesiastical influence is grounded in a specific experience that makes sense only within the historical context of church-state strife. Only the church's attempt to subordinate supreme political power to its own authority, its scrambling for the riches of this world as it were, can be held responsible for the virulence of the antireligious sentiment that characterized the Enlightenment. However, this specifically if not uniquely bitter western experience renders the secularist solution to the alleviation of sacred-secular tension within modern society much less of a universal cure.

For all the benefits of the secularization process, it cannot be transferred facilely to other cultures, for they do not share with the West the "medieval" experience of ecclesiastical tyranny and obscurantism. Thus the odd Muslim thinker who proposes a conscious policy of secularization for the modernization of Muslim societies may be criticized justifiably for not understanding the dialectics of either Muslim or western history. ${ }^{2.5}$ Furthermore, Muslim secularists are frustratingly reticent as to the mechanics of this process. They never spell out how, in the absence of the 
church-state dichotomy, and by which institutional mechanism, the churchless Islamic societies may trigger this process (as compared, for instance, to the legal and political appropriation of ecclesiastical property for "worldly" uses, which is the western precedent). The secularist solution, then, does not move beyond stating the problem and provides no indication that a superficial reading of Islam as a fait social can comprehend sensitively its historical crisis and prescribe any cure for its cultural malaise.

\section{No Limits to Power!}

The most respectable theory with regard to secularism is the one that portrays it not only as the breakdown of ecclesiastical authority but also as the collapse of the theocentric model of the universe. It construes the development of secularism in terms of a devolution of human consciousness "from Divine Cosmos to Sovereign State." ${ }^{\text {"6 }}$ Within a secular political order, it is argued, concerns with temporality and mortality replace the search for immortality and a transtemporal salvation. Secularization entails journeying into modernity and partaking of its sacraments of rationality and progress. ${ }^{27}$ In modernity, humanity creates not only the self, which is the historical and cultural medium for redemption, but also the representative secular sovereign state that renders human reliance on any benign cosmic and theocratic order superfluous. Secularity, quite simply, is humanity's coming of age.

Obviously, the modern march away from theocracy to secularism signals a new conception of "reality" in political philosophy. Secularism selfconsciously repudiates the Christian solution to the human condition: that the true end of humanity lies beyond the world of politics and history. ${ }^{28}$ In the name of realism, it posits a new conception not only of the polis but also of the cosmos. Indeed, there is a general turn away from transcendentalism to immanentism, from theology to positivism and historicism, which renders politics more an art of the possible than a quest for virtue, justice, or redemption..$^{29}$ The architect of modern political realism and the first theorist of the modern secular state is none other than Machiavelli. Religion, declared Machiavelli, has to be banished from politics not because it teaches morality but because it teaches the wrong kind of morality, the kind that does not enhance the power of the state. For him, the religious claim to rule over the secular realm (church vs. state) produces only two alternatives: the public realm becomes corrupt, in which case religion itself is abused, or the religious body remains incorrupt and hence destroys the public realm altogether. Either a corrupt state and the doom of religion, or an uncorrupted religion and the ruination of the state.

The church-state dialectic has been long recognized as posing an almost insoluble problem for the Christian conscience. Expressed more cautiously, "there are no absolute relationships of church and state, of religion and politics, and perhaps no ideal ones either." The state, being the 
outcome of the original sin, is at best a necessary evil, and politics, to the extent that it incarnates the sheer struggle for power, "is bound, in Christian terms, to be the realm of the devil by definition." ${ }^{\prime 30}$ The church, in other words, may neither forsake the state nor claim it as its own. Paradoxically, the Machiavellian and the Christian concepts of politics, despite their radically diametric moral foundations, are identical insofar as they both result in a devaluation of politics. Politics is not a quest for virtue or justice, but is, at best, an activity proper either to a fallen humanity (Christianity) or to the half-human, half-beastly statesman (Machiavellianism).

The traditional vision of Christianity as "Christendom" was at best an uneasy balancing act, for it was neither obliged to dismiss instrumental goods nor to encourage a theocratic temptation. But, even this Christian compromise crumbled in history and was replaced by a modernity in which politics, arts, science, and philosophy asserted their autonomy from divine supervision. Modernity, however, created its own impasse, namely, that if each of these domains of the human spirit had to look for its own criteria of validity beyond and outside the biblical tradition and the church, where was this normative foundation to be and how could it produce $e x$ nihilo its own principles without making them a matter of arbitrary choice? The crisis of authority was already present in the secularist's quest for autonomy. But while art, and perhaps philosophy and science, could live with this nihilistic liberation, it cannot be made an unrestrained principle of politics, for politics, in order to remain politics, needs to distinguish itself from anarchy.

This brings us to the poverty of secular polemics against religious faith, for it misconstrues theocracy, either by incapacity or by design, as a theory of politics and a model for governance. Theocracy, however, is preeminently a moral doctrine that proclaims the futility of "political solutions" or the illegitimacy of secular rule. ${ }^{31}$ It represents a utopia that, as observed acutely by a modern philosopher, "is a form of suggestiveness from afar. It is not primarily a project of action but a critique of the present." ${ }^{32}$ Theocracy, accordingly, cannot be institutionalized and must be distinguished from hierocracy, or clerocracy, which simply stand for "priestly government." In terms of its moral orientations and relationship to power and truth, then, the theocratic perception is the exact opposite of its secular counterpart, for secularism proclaims not only a doctrine of power but also its supremacy over truth. Truth is merely a mask that the will-to-power wears in order to realize itself. Indeed, in its Nietzschean form, secularism aims right at the heart of religious faith by claiming that power is, essentially and ultimately, amoral. Of course, it is a stupendous claim that can be sustained only within the consciousness of nihilism, a consciousness convinced of the "death of God."

Given the amoral nature of the secularist truth, it is not accidental that the highest secularist power-the modern antitheocratic state-claims for itself the morally indefensible attribute of "sovereignty." The distinguish- 
ing characteristics of a sovereign power, according to a modern theorist, are: "its possession of a legislative authority; its capacity to alter as it pleases its subjects' rules of behavior, while recasting at its own convenience the rules which undermine its own; and, while it legislates for others, to be itself above the laws, legibus solutus, absolute." ${ }^{33}$ Similar misgivings have been expressed from the radically different vantage point of political science. The concept of sovereignty refers to some idea of moral goodness, to something intrinsically valid and commanding that lies outside the realm of procedures and juridicality. The state as a formal legal entity cannot incorporate it and produce its own legitimacy by claiming it. ${ }^{34}$

From the point of view of political philosophy and not merely that of jurisprudence, a modern Catholic thinker pleads that "the concept of sovereignty is intrinsically wrong. ${ }^{135}$ The source of the logical, not to speak of the moral, error lay in the original concept advanced by Jean Bodin, who separated the Sovereign from the body politic. The sovereignty of the people is likewise untenable, for "it is nonsensical to conceive of the people as governing themselves separately from themselves and from above themselves. ${ }^{136}$ Rousseau compounded the problem by endowing the concept with another mystical notion: the general will. Rousseau's mythical and totalitarian entity stipulated the sovereignty of the people as a whole but excluded the possibility of any particular citizen bodies or associations enjoying with the state any kind of autonomy! Finally, the doctrine of sovereignty required that no decision made by the Sovereign, whether conceived as the mortal God or the general will, could possibly be resisted by the individual conscience in the name of justice.

The concept of sovereignty, being one with that of absolutism, must be done away with, as well as the claim of the nonaccountability of the state. The result of the presence of these two concepts in modern political theory has been the transferral of power without the accountability of the personal and absolutist Sovereign to the so-called legal personality of the state. However, the concept of sovereignty, even if improper to political philosophy, is proper to theology, for "it loses its poison when it is transplanted from politics to metaphysics. In the spiritual sphere there is a valid concept of Sovereignty. God, the separate Whole, is sovereign over the created world." ${ }^{17}$ In any case, state sovereignty is no guarantee of justice and righteousness: Even a Nazi state, construed strictly and legally within its formal framework, is still sovereign and legitimate! Little wonder that the most disquieting consequences of the Nietzschean concept of amoral power is that genocide has become the measure of civilization itself. ${ }^{38}$

Secularism does not present a unified theory or a systematic doctrine, and the Muslim critic must resist the temptation of imparting to it a theoretical and epistemological unity that it manifestly lacks. Secularism, in short, must not be sanctified as a "grand theory" or the "master paradigm" of the West. Like any other human reality, western civilization is beset by its own inner contradictions that do not lend themselves to the postulation of an absolute theoretical unity. Indeed, the only lesson worth learning out 
of this exercise is about the complexity and richness of human experience and the inadequacy and poverty of theory. Or, as Goethe has expressed so eloquently:

\section{Grau, teurer Freund, is alle Theorie.} Und grün des Lebens goldner Baum.

(Gray, my dear friend, is every theory, And green alone life's golden tree.)

In addition, we must avoid looking at the ideational landscape of our times as a battlefield between theocracy and western secularism. The contest is not between Islam and modernity or between Islamic faith and secular rationality. Indeed, it is not even between a Muslim will-to-power and a secular world order that solicits a cultural and political pluralism, but rather between faith in a transcendent being and the totalitarian project for an immanent social utopia conceived as the end (al äkhirah). So long as the western individual, or the Muslim fundamentalist for that matter, takes it upon himself/herself to act as the advocate of secularism, and so long as that same person, whatever his/her descent and persuasion, is adamant upon renouncing transcendence, homo islamicus has no other option but to stand firm in his/her faith in an ultimately transsecular order of reality.

\section{Endnotes:}

1. H. Lübbe, Sakulariserund: Geschichte eines ideenpolitischen Begriffs (Freiburg, Germany: Alberg, 1965).

2. Dietrich Bönhoffer, Ethics (New York: Macmillan, 1959); E. Bethge, Die mündige Welt, 2 vols. (Munich: Kaiser, 1955-56); Cox, 1-2.

3. H. Blumenberg, The Legitimacy of the Modern Age (Cambridge, MA and London: MIT Press, 1984).

4. Peter Berger, The Social Reality of Religion (Hammondsworth, UK: Penguin Books, 1973), 112.

5. Ibid., 113.

6. David A. Martin, The Religious and the Secular (London: Routledge \& Kegan Paul, 1969), 9.

7. J. Hadden and A. Shupe (eds.), "Secularization and Fundamentalism Reconsidered," in Religion and Political Order, vol. 3 (New York: Paragon, 1989), xv.

8. Hadden, in Hadden and Shupe, 13.

9. Ibid., 4.

10. Ibid., 20.

11. Berger, Social Reality of Religion, 113.

12. G. Vattimo, The End of Modernity (Oxford: Polity Press, 1988), 100.

13. W. C. Smith, The Meaning and End of Religion (New York: 1962).

14. Ibid.

15. Talal Asad, Genealogies of Religion: Discipline and Reasons of Power in Christianity and Islam (Baltimore: The Johns Hopkins University Press, 1993), 29.

16. Hannah Arendt, Modernity and the Holocaust (Oxford: Polity Press, 1991), 122.

17 lbid., 127.

18. Ibid., 128. 
19. Ibid., 140.

20. Michael Harrington, The Politics at God's Funeral (New York: Holt, Rinehart \& Winston, 1983).

21. Ibid., 708 (emphasis added).

22. Ibid., 8.

23. Berger, Social Reality, 1973.

24. Oliver Roy, The Failure of Political Islam (Cambridge, MA: Harvard University Press, 1994), 45.

25. Bassam Tibi, Islam and the Cultural Accommodation of Social Change (Boulder, San Francisco, and Oxford: Westview Press, 1990), 39.

26. Stephen L. Collins, From Divine Cosmos to Sovereign State (Oxford and New York: Oxford University Press, 1989).

27. Sam Whimster and Scott Lash (eds.), Max Weber, Rationality and Modernity (London and Boston: Allen Unwin, 1987).

28. James V. Schall, Reason, Revelation, and the Foundation of Political Philosophy (Baton Rouge: Louisiana University Press, 1987).

29. Peter 1. Kaufman, Redeeming Politics (Princeton: Princeton University Press. 1990); Leo Strauss, Natural Right and History (Chicago: University of Chicago Press, 1953).

30. L. Kolakowsky, Modernity on Endless Trial (Chicago: Chicago University Press, 1990), 175.

31. Martin Buber, Kingship of God (New Jersey and London: Humanities Press International, 1967); J. Wellhausen, Die religiös-politischen Oppositionsparteien im alten Islam (Göttingen, Germany: 1980, trans. R. C. Ostle and S. M. Walzer): The ReligioPolitical Factions in Early Islam. Amsterdam: North Holland, 1975. 80.

32. H. Gadamer, Reason in the Age of Science (Cambridge, MA: MIT Press, 1981),

33. Bertrand De Jouvenel, On Power: The Natural History of Its Growth (Indianapolis: Liberty Fund, 1993), 31. (Original French edition, 1945).

34. Carl Schmitt, Political Theology: Four Chapters on the Concept of Sovereignty (Cambridge, MA: MIT Press, 1988). (Original German edition, 1922/34).

35. Jacques Maritain, Man and the State (Chicago: Chicago University Press, 1951), 29.

36. Ibid., 44.

37. Ibid., 49.

38. Z. Bauman, Modernity and the Holocaust (Oxford, UK: Polity Press, 1991). 